\title{
Article \\ Plant Extracts for the Control of Listeria monocytogenes in Meat Products
}

\author{
Simona de Niederhäusern, Moreno Bondi (D), Stefania Camellini (D), Carla Sabia (D), Patrizia Messi (D) and \\ Ramona Iseppi * (D)
}

Citation: de Niederhäusern, S.; Bondi, M.; Camellini, S.; Sabia, C.; Messi, P.; Iseppi, R. Plant Extracts for the Control of Listeria monocytogenes in Meat Products. Appl. Sci. 2021, 11, 10820. https://doi.org/10.3390/ app112210820

Academic Editors: Antonio Valero and Alessandra Durazzo

Received: 30 September 2021 Accepted: 12 November 2021 Published: 16 November 2021

Publisher's Note: MDPI stays neutral with regard to jurisdictional claims in published maps and institutional affiliations.

Copyright: (C) 2021 by the authors Licensee MDPI, Basel, Switzerland. This article is an open access article distributed under the terms and conditions of the Creative Commons Attribution (CC BY) license (https:// creativecommons.org/licenses/by/ $4.0 /)$.
Department of Life Sciences, University of Modena and Reggio Emilia, Via G. Campi 287, 41125 Modena, Italy; denieder.simona@gmail.com (S.d.N.); moreno.bondi@unimore.it (M.B.); stefania.camellini@unimore.it (S.C.); carla.sabia@unimore.it (C.S.); patrizia.messi@unimore.it (P.M.)

* Correspondence: ramona.iseppi@unimore.it; Tel.: +39-(05)-92055469

\begin{abstract}
The antimicrobial activity of garlic (Allium sativum L.) and onion (Allium cepa L.) plant active extracts was determined against Listeria monocytogenes in two meat products. Samples of sausages "cacciatore" and cooked ham in vacuum-packaged slices were artificially contaminated, and the presence of Listeria was evaluated during the sausages ripening and throughout the shelf-life of the cooked ham. The test carried out on sausages did not show differences among treated and untreated samples. The antagonistic activity of the plant extracts against the pathogen was probably hidden by the competition from the sausages microbial flora and the $\mathrm{pH}$ and the water activity (aw) decrease. On the other hand, the plant extracts determined an initial reduction of about $1.00 \mathrm{log} \mathrm{cfu} / \mathrm{g}$ of the L. monocytogenes viable count in the cooked ham slices contaminated with $10^{3} \mathrm{cfu} / \mathrm{g}$, but the best result was obtained with the contamination of $10^{2} \mathrm{cfu} / \mathrm{g}$ of L. monocytogenes. In addition to the pathogen's initial decrease, we observed an extension of the lag phase and a reduction of the Listeria growth rate. Considering that the presence of L. monocytogenes during the slicing phase of the cooked ham does not exceed $10 \mathrm{cfu} / \mathrm{g}$, the use of plant extracts can lead to complete pathogen elimination.
\end{abstract}

Keywords: plant extracts; antimicrobial activity; sausages; cooked ham; Listeria monocytogenes

\section{Introduction}

The need to produce healthy and safe food without the use of chemical additives has led to the development of technologies for the control of both pathogenic and spoilage microorganisms and consequently high-quality standards. This requirement comes from the consumers demanding safe and quality food products but, at the same time, little processing, with a low content of chemical additives and with an extended shelf-life [1]. The main innovative conservation techniques optimized and available for food applications are based on the implementation of high pressure [2], active packaging [3-5] and natural antimicrobial compounds [6-10]. The growing interest in food bio-conservation has led to the use of new antimicrobial compounds of various origins, including those based on the use of microorganisms, their metabolites and natural extracts of plant origin [11-13]. A wide range of hams and sausages can be found on the market, with their characteristics deriving from different product recipes, raw materials and processing conditions, which are also related to the climatic conditions and to the specific origin of the raw meats. Consequently, different recipes and processing methods give the products different organoleptic characteristics. Italian Salami and hams are made with fresh, carefully selected Italian pork, with spices added to refine the taste of the meat: this is a fundamental step to enhance the scent of the final product, and is essential to shape the different tastes, which are typical of specific territories [14]. The spices are added during the preparation of foods with the aim of improving their organoleptic characteristics. Furthermore, the antioxidant action carried out by the molecules that compose the spices can contribute significantly to the prevention of natural food alteration phenomena (oxidative phenomena) with an 
advantage for the final consumer as well [15]. Since ancient times, spices have been used for the control of microbial alterations and for their antimicrobial activity in food [16-18]. Spices such as cinnamon, cloves, garlic, mustard and onion can increase the commercial life of foods thanks to the content of some biologically active compounds consisting of phenols, aldehydes, ketones, ethers and hydrocarbons. Several studies carried out using other spices, such as laurel, coriander, rosemary, thyme, oregano and sage, have shown their significant bacteriostatic effect [19-21]. Some authors have described the use of these natural extracts for the preservation of fresh meat, fish products and fresh cheeses [15,20]. Some extracts are not only able to control the development of altering microorganisms but, by prolonging the shelf-life, they allow for a general increase in quality itself [22-26]. Spices, in addition to exhibiting antimicrobial action against certain foodborne pathogens, have a stimulating action towards lactic acid bacteria, used as starters in seasoned meat products and fundamental protagonists of fermentation processes. In fact, the presence of lactic acid bacteria has a positive impact on fermented products only, whereas in non-fermented or cooked meat products, they can be involved with food spoilage if a cross-contamination post thermal process happens [27]. The stimulus action seems to be dependent not only on the type of spices and their origin, but also on the different types of microbial population present in the food [28,29]. Different extracts of spices can be effectively used as natural additives alone or in combination with other conservation technologies. They can act on food preservation with an inhibitory effect on the spoilage microbial population, both Gram-positive and Gram-negative bacteria. However, their effectiveness changes according to $\mathrm{pH}$, storage temperature, oxygen presence and the concentration of biologically active components responsible for antimicrobial activity [30]. For this reason, evaluating spices in food, and evaluating food structure, composition and interaction between natural microflora and foodborne bacteria should be done for their use as natural alternatives to chemical compounds (i.e., nitrites and nitrates) that are employed in the control of unwanted microorganisms. The aim of this study, realized in collaboration with the experimental station for the food preserving industry-S.S.I.C.A., Parma, Italy, was the achievement of two different objectives: (i) to assay the antimicrobial activity of a plant active extract from garlic (Allium sativum L.) and onion (Allium cepa L.) against an important foodborne pathogens, Listeria monocytogenes, added during the sausages' manufacturing process; and (ii) to evaluate the effectiveness of the same vegetable extract during the shelf-life of packed vacuum-cooked ham slices that were artificially contaminated with $L$. monocytogenes.

\section{Materials and Methods}

\subsection{Plant Extracts, Strains and Culture Conditions}

The plant extract employed is a natural concentrated product containing active ingredients obtained by hydro-distillation of fresh and dried garlic (Allium sativum L.) and onion (Allium cepa L.), and considered safe (GRAS) by the Food and Drug Administration (FDA). The garlic and the onion plant extracts were used, as they are often employed, to flavor sausages. To make the extracts, $30 \mathrm{~g}$ of garlic and onion, respectively, were placed in infusion in a flask containing $300 \mathrm{~mL}$ of sterile distilled water for one hour. After this time, the mixture was stirred and allowed to stand at room temperature for $24 \mathrm{~h}$. Four extraction cycles using dichloromethane $(30 \mathrm{~mL})$ and one extraction with diethyl ether $(30 \mathrm{~mL})$ were performed on each. All the fractions were collected into a sterile flask and dried over anhydrous sodium sulphate. After $24 \mathrm{~h}$, the extracts were concentrated under reduced pressure in a rotary evaporator and were stored at $-20^{\circ} \mathrm{C}$ for further analysis. The compounds of extract from garlic and onion were analyzed and identified by GC-FID and GC-MS. 
A cocktail of five Listeria monocytogenes strains from different sources was used in the study based on their different sensitivity to the extracts tested as shown by the minimum inhibitory concentration (MIC) values. The mixture of Listeria included L. monocytogenes CSA10, L. monocytogenes 10P and L. monocytogenes 123 (belonging to the experimental station for the food preserving industry-S.S.I.C.A., Parma, Italy SSICA collection), previously isolated from sausages and cooked ham, and L. monocytogenes Scott A (from National Laboratories of Foods and Drugs) and L. monocytogenes ATCC 7644 (from American Type Culture Collection).

Overnight cultures of Listeria strains were grown at $37^{\circ} \mathrm{C}$ in $5 \mathrm{~mL}$ of Tryptic Soy Broth (TSB, Oxoid, Milan, Italy), and collected and centrifuged (Eppendorf Centrifuge $5417 \mathrm{r}$, Eppendorf s.r.1., Milan, Italy) at $4000 \mathrm{rpm}(66.70 \mathrm{~Hz})$ at $4{ }^{\circ} \mathrm{C}$ for $15 \mathrm{~min}$. The pellet of each strain was suspended in $9 \mathrm{~mL}$ of sterile peptone saline solution (Oxoid, Milan, Italy), enumerated as colony-forming units per milliliter $(\mathrm{cfu} / \mathrm{mL})$ on Tryptic Soy Agar (TSA, Oxoid, Milan, Italy) and stored at a refrigerated temperature $\left(4^{\circ} \mathrm{C}\right)$ for $4 \mathrm{~h}$ before contaminating the samples.

The inoculum for the sausage contamination was carried out by adding the cocktail of Listeria to the standard dough then stirred by hand to obtain a uniform distribution of about $10^{5} \mathrm{cfu} / \mathrm{g}$ of the pathogen. In this case, a high contamination charge $\left(10^{5} \mathrm{cfu} / \mathrm{g}\right)$ is required considering that the product, consisting of minced meat, presents a large exposed surface.

To validate the concentration and the uniform distribution of the artificial contamination, the inoculated pathogens were counted (cfu/g) by taking $25 \mathrm{~g}$ samples in six different positions of the standard dough immediately after preparation (time 0 ). Approximately 4 $\mathrm{h}$ after bagging and before drying and ripening treatments, other three samples per line were analyzed removing three $25 \mathrm{~g}$ portions from the core, the top and the bottom of sausages. The portions of each sausage were diluted in a 1:10 ratio with sterile peptone saline medium and homogenized for $2 \mathrm{~min}$ in a stomacher (Lab Blender, Seward, London, UK). L. monocytogenes viable counts were determined by spreading on Palcam Agar Base (Oxoid, Milan, Italy) plates and incubated aerobically at $37^{\circ} \mathrm{C}$ for $48 \mathrm{~h}$. The samplings were then repeated at established times $(1,3,8,17,21$ and 28 days) in the same way. For the cooked ham, the contamination was performed by spreading the L. monocytogenes mixture on the surface of square slices of the product and dispensed with a sterile glass spatula, to obtain a uniform inoculum of about $10^{3}$ or $10^{2} \mathrm{cfu} / \mathrm{g}$.

\subsection{Minimum Inhibitory Concentration (MIC) Determination}

The extracts MIC values were determined against all microorganisms by the broth microdilution method in 96-well microplates, according to the Clinical Laboratory Standards Institute (CLSI) guidelines from 2019 [31]. For each strain, an overnight culture was diluted in a sterile TSB to the final concentration of $10^{6} \mathrm{cfu} / \mathrm{mL}$, and $5 \mu \mathrm{L}$ were dispensed into each well of a sterile 96-well plate with $95 \mu \mathrm{L}$ of TSB. Then, 100 $\mu \mathrm{L}$ of extracts serial dilutions were added to obtain concentrations ranging from 512 to $0.125 \mu \mathrm{L} / \mathrm{mL}$. Negative control wells consisted of bacteria in TSB without extracts. The plates were mixed on a plate shaker at $300 \mathrm{rpm}$ for $20 \mathrm{~s}$ and incubated at $37^{\circ} \mathrm{C}$ for $24 \mathrm{~h}$. The MIC value was defined as the lowest extracts concentration able to inhibit a visible growth of the target microorganism, compared to the growth in the positive control, after the optical density (OD) measure at $570 \mathrm{~nm}$ using a microtiter-plate reader (Sunrise ${ }^{\mathrm{TM}}$, Tecan Trading AG, Männedorf, Switzerland). All the experiments were repeated three times.

\subsection{Growth Control of L. monocytogenes by Plant Extracts in Artificially Contaminated Sausages}

The standard dough used to produce sausages "cacciatore" consists of ground pork meat added with $\mathrm{NaCl} 2.8 \%(w / w)$, black pepper in wheat $0.2 \%(w / w)$, milk powder $3 \%$ $(w / w)$ (containing up to $60 \%(w / w)$ lactose), $0.015 \%$ sugar, sodium ascorbate and sodium nitrite. About $24 \mathrm{~kg}$ of standard dough was divided into two portions, one of $12 \mathrm{~kg}$ used 
as the control and one of $12 \mathrm{~kg}$ that was contaminated before packing with a cocktail of $L$. monocytogenes.

The portion inoculated with L. monocytogenes was further divided into two batches, one of which was added with $10 \mu \mathrm{L} / \mathrm{g}$ of the plant extract (about $3 \mathrm{~mL} /$ sausage, garlic and onion were added in a same ratio of $0.05 \%$ ) based on data obtained from preliminary in vitro evaluations. We obtained 18 non-inoculated sausages (C-control), 18 noninoculated sausages with plant extract added $(10 \mu \mathrm{L} / \mathrm{g})(\mathrm{PEC}$ - plant extract control), 18 sausages contaminated with $L$. monocytogenes mixture (LMC) and 18 inoculated with $L$. monocytogenes mixture and plant extract (PELM) (Table 1).

Table 1. Inoculation trials in sausages "cacciatore".

(C)-Standard Dough

(PEC) - Standard Dough with Plant Extracts Added $(10 \mu \mathrm{L} / \mathrm{g})$

(LMC) — standard dough with cocktail of L. monocytogenes added (about $10^{5} \mathrm{cfu} / \mathrm{g}$ )

(PELM) - standard dough with cocktail of L. monocytogenes and plant extracts added $(10 \mu \mathrm{L} / \mathrm{g})$

\subsection{Production and Ripening of Sausages}

The inoculated and non-inoculated standard doughs, with all components uniformly distributed by hand in sterile bags made of pliant, highly resistant polyethylene (VWR International Srl, Milan, Italy), were stuffed into a $5 \mathrm{~cm}$ diameter natural casing using a mechanical stuffer. The obtained sausages, of about $25 \mathrm{~cm}$ long and $300 \mathrm{~g}$ in weight, according to the ripening parameters adopted by the producer, were dried at $24{ }^{\circ} \mathrm{C}$ and $55 \%-70 \%$ relative humidity for $10-12 \mathrm{~h}$ and subsequently stored at $12{ }^{\circ} \mathrm{C}$ and humidity of $80 \%-85 \%$ for 28 days. All stages of production were carried out in a suitable pilot plant equipped with temperature and humidity control programs and subjected to periodic environmental microbiological controls.

\subsection{Microbiological Parameters of Sausages}

Approximately four hours after bagging and before drying and ripening treatments, three samples per line were analyzed to verify the level of initial artificial contaminants (cfu/g) (time 1). At the same time, the viable count of mesophilic bacteria (colony count at $30{ }^{\circ} \mathrm{C}$; ISO 4833-1:2013) [32], lactic acid bacteria (ISO 15214:1998) [33], Micrococcus and Staphylococcus spp. (UNI EN ISO 6888-1:2004) [34], Staphylococcus aureus (UNI EN ISO 6888-1:2004) [34] and Enterobacteriaceae (ISO 21528-2:2004) [35], as well as the detection in $25 \mathrm{~g}$ of L. monocytogenes (UNI EN ISO 11290-1:2005) [36] and Salmonella spp. (UNI EN ISO 6579:2008) [37], were determined. Afterwards, to investigate the trend of the inoculated pathogens, three sausage samples were analyzed for each established time $(1,3,8,17,21$ and 28 days). Microbiological investigations were performed after preparation (time 1 ), after drying (3-8 days), at half ripening (8th day), at final ripening (17th day) and during and after storage at $4{ }^{\circ} \mathrm{C}$ (21-28th day). After removing the natural casing, $25 \mathrm{~g}$ portions of each sausage were diluted in a 1:10 ratio with sterile peptone saline medium and homogenized for $2 \mathrm{~min}$ in a stomacher (Lab Blender, Seward, London, UK). L. monocytogenes viable counts were determined by direct spread plating in Aloa agar (Biolife, Milan, Italy) and by the EN ISO 11290-2: 2017 method [38].

\subsection{Growth Control of L. monocytogenes by Plant Extracts in Artificially Contaminated Cooked Ham Slices}

To determine the anti-listerial potential of the plant extracts added to cooked ham, the test was conducted according to the "Technical guidance document for conducting shelf-life studies on Listeria monocytogenes in ready-to-eat foods (2014)" [39]. From a whole cooked ham, 120 square slices of $15 \mathrm{~g}$ were cut and overlapped at sandwich to obtain a total of 60 samples of about $30 \mathrm{~g}$ weight. Using a vacuum-packaging machine (LAPACK 450 LCD), 9 control samples (C-control) were packaged and 9 samples were added only with $10 \mu \mathrm{L} / \mathrm{g}$ of plant extracts (PEC-plant extracts control) (garlic and 
onion were added in a same ratio of $0.05 \%)$. Notably, 9 samples of both CLM3 and PELM3 were inoculated with a mixture of L. monocytogenes to obtain $10^{3} \mathrm{cfu} / \mathrm{g}$, while samples of both CLM2 and PELM2 were inoculated with a mixture of approximately $10^{2}$ $\mathrm{cfu} / \mathrm{g}$ of Listeria (Table 2).

Table 2. Inoculation trials in cooked ham slices.

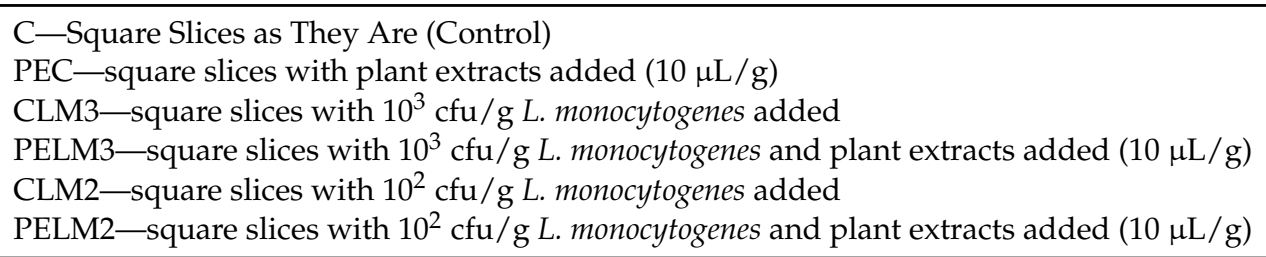

Controls and inoculated samples were then stored at $4{ }^{\circ} \mathrm{C}$ until the 28th day (shelf-life of the product). L. monocytogenes viable counts (cfu/g) were assessed by the direct platecounting method (ISO 4833-1:2013) [32], analyzing 3 cooked ham slices of the different lines at the indicated times $(1,5,8,12,15,20$ and 28 days). Physico-chemical parameters ( $\mathrm{pH}$ and aw) were measured with a temperature and humidity control program, as previously described for sausages, on 3 samples from the $C$ and PEC lines.

The effectiveness of plant extracts in cooked ham was tested by the rate of L. monocytogenes growth in treated and untreated samples using MicroFit $\odot$. Through this software processing, it was also possible to obtain parameters such as initial and final concentration of Listeria, maximum growth rate, latency phase and generation time.

\subsection{Statistical Analysis}

The data obtained, relative to the growth of L. monocytogenes, were modelled using MicroFit@ (Institute of Food Research, Norwich, UK), a predictive microbiology software. This software processes a graph with experimental points and the regression curve derived from the use of the Baranyi and Roberts's primary model.

Each experiment was replicated three times. The statistical significance was determined by the $t$-test and ANOVA test using statistical program GraphPad Prism 9.2.0. (San Diego, CA, USA). The $p$-values were declared significant at $\leq 0.05$.

\section{Results}

\subsection{Minimum Inhibitory Concentration (MIC) Determination}

MICs of garlic and onion extracts are shown in Table 3. The growth of Listeria was inhibited by garlic and onion extracts from 8 to $32 \mu \mathrm{L} / \mathrm{mL}$ and from 4 to $32 \mu \mathrm{L} / \mathrm{mL}$, respectively. The major components of onion extract were dimethyl-trisulfide $(13.40 \%)$, me-thyl-propyl-trisulfide (11.36\%), methyl-(1-propenyl)-disulfide (16.11\%) and me-thyl(1-propenyl)-trisulfide (14.16\%). While the major constituents of garlic EO were diallyltrisulfide (36.28\%), diallyl-disulfide (25.42\%) and methyl-allyl-trisulfide (10.12\%). The high content of organo-sulfur compounds found in garlic and onion cause their antibacterial activities [40].

Table 3. Minimum and maximum value of minimum inhibitory concentration (MIC) of plant extracts. Data are expressed as $\mu \mathrm{L} / \mathrm{mL}$.

\begin{tabular}{ccc}
\hline Strains & Garlic Extract & Onion Extract \\
\hline L. monocytogenes CSA10 & $8.00-16.00$ & $8.00-16.00$ \\
L. monocytogenes 10P & $16.00-32.00$ & $4.00-8.00$ \\
L. monocytogenes 123 & 32.00 & 8.00 \\
L. monocytogenes Scott & $8.00-16.00$ & $16.00-32.00$ \\
L. monocytogenes ATCC 7644 & 8.00 & 4.00 \\
\hline
\end{tabular}




\subsection{Growth Control of L. monocytogenes by Plant Extracts in Artificially Contaminated Sausages}

The results of the study conducted on sausages, untreated (LMC) and treated (PELM) with plant extracts and contaminated with L. monocytogenes, are shown in Figure 1.

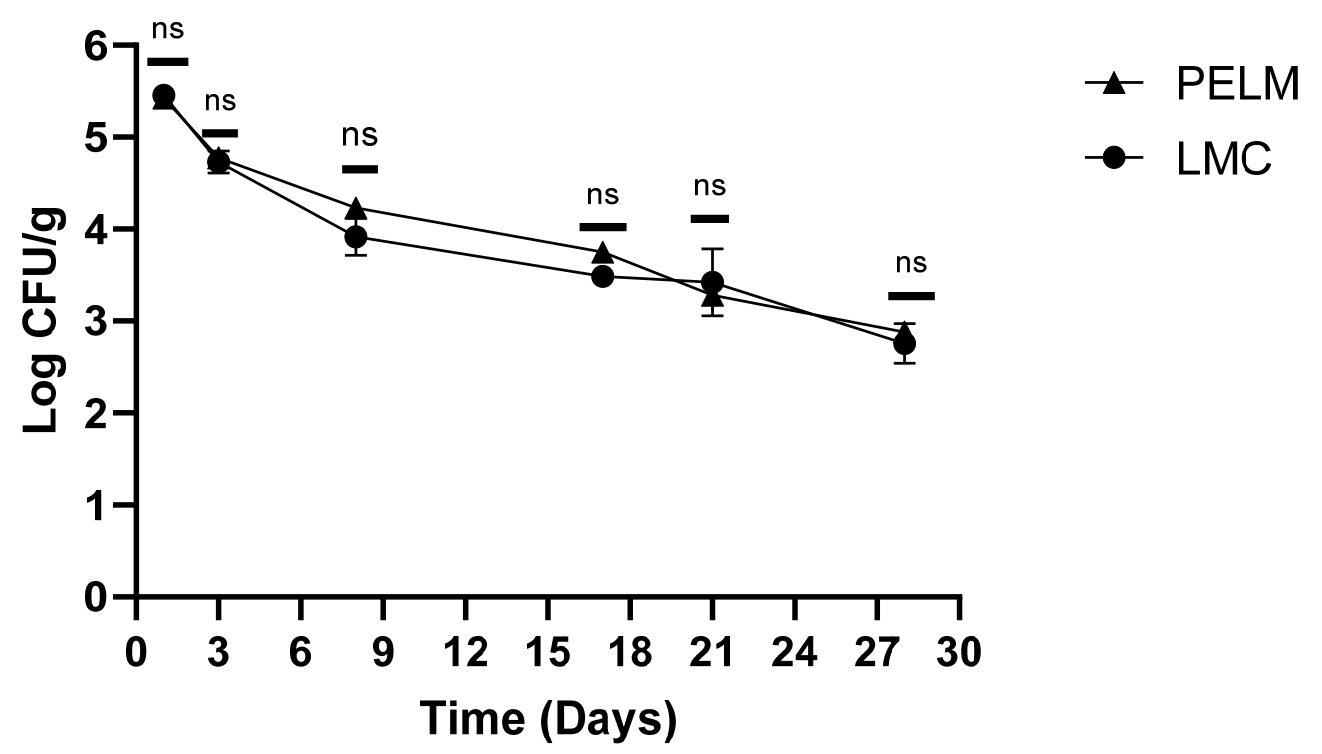

Figure 1. Trend of L. monocytogenes during the sausages production with (PELM) and without (LMC) plant extract. $p$-values of ${ }^{*}<0.05,{ }^{* *} p<0.01,{ }^{* * *} p<0.001$ and ${ }^{* * *} p<0.0001$ were considered significant by $t$-test and ANOVA. ns means not significant.

During the sausage production in both types of samples (treated and untreated), a progressive decrease in L. monocytogenes viable count was observed. In untreated samples (LMC) from an initial viable count of $5.46 \mathrm{log} \mathrm{cfu} / \mathrm{g}$, a reduction up to values of $4.73 \mathrm{log}$ $\mathrm{cfu} / \mathrm{g}$ was detected after the first 3 days (fermentation phase). In the following sampling, the decrease was constant until reaching $2.60 \mathrm{log} \mathrm{cfu} / \mathrm{g}$ at the end of the seasoning (decimal reductions of $2.86 \log \mathrm{cfu} / \mathrm{g}$ ).

In sausages treated with plant extracts (PELM) analogous results were recorded: From an initial Listeria viable count of $5.43 \mathrm{log} \mathrm{cfu} / \mathrm{g}$, we observed a value of $2.88 \mathrm{log} \mathrm{cfu} / \mathrm{g}$ (decimal reduction equal to $2.55 \mathrm{log} \mathrm{cfu} / \mathrm{g}$ ) at end seasoning. The only difference was found on the 17th day, with a difference between LMC and PELM of $0.26 \mathrm{log}$.

\subsection{Microbiological Parameters of Sausages}

The standard dough at the time of receipt showed a microbial profile characterized mainly by lactic acid bacteria (LAB) and Micrococcaceae (6.36 and $6.13 \mathrm{log} \mathrm{cfu} / \mathrm{g}$ respectively). This natural bacterial flora, normally present in the raw material of the sausages "cacciatore" and, in particular, the lactic acid bacteria growth during seasoning, are important to promote the organoleptic and physicochemical characteristics of the product.

Lower values were detected for Enterobacteriaceae and Staphylococcus aureus (3.34 and $1.13 \log \mathrm{cfu} / \mathrm{g}$ viable counts, respectively) while L. monocytogenes and Salmonella spp. were absent in $25 \mathrm{~g}$. These data demonstrate a good quality of the raw material (Table 4). 
Table 4. Evaluation of the microbial flora in sausages.

\begin{tabular}{|c|c|c|c|c|c|}
\hline \multirow{2}{*}{$\begin{array}{l}\text { Sampling } \\
\text { (Days) }\end{array}$} & \multicolumn{5}{|c|}{ Microbial Profile (log cfu/g) } \\
\hline & $\begin{array}{c}\text { Mesophilic } \\
\text { Bacteria }\end{array}$ & $\begin{array}{c}\text { Lactic Acid } \\
\text { Bacteria }\end{array}$ & Micrococcaceae & Enterobacteriaceae & $\begin{array}{c}\text { Staphylococcus } \\
\text { aureus }\end{array}$ \\
\hline 1 & $6.58 \pm 0.10$ & $6.36 \pm 0.22$ & $6.13 \pm 0.23$ & $3.34 \pm 0.12$ & $1.13 \pm 0.21$ \\
\hline 3 & $8.73 \pm 0.18$ & $8.69 \pm 0.31$ & $6.88 \pm 0.11$ & $1.78 \pm 0.16$ & $1.70 \pm 0.09$ \\
\hline 8 & $8.75 \pm 0.22$ & $8.72 \pm 0.18$ & $5.57 \pm 0.08$ & $0.70 \pm 0.21$ & $1.70 \pm 0.07$ \\
\hline 17 & $8.52 \pm 0.11$ & $8.47 \pm 0.15$ & $5.78 \pm 0.06$ & $0.70 \pm 0.15$ & $1.70 \pm 0.18$ \\
\hline 21 & $8.26 \pm 0.15$ & $8.24 \pm 0.06$ & $6.02 \pm 0.11$ & $0.70 \pm 0.23$ & $1.70 \pm 0.11$ \\
\hline 28 & $8.51 \pm 0.08$ & $8.37 \pm 0.10$ & $5.88 \pm 0.15$ & $0.70 \pm 0.28$ & $1.70 \pm 0.16$ \\
\hline
\end{tabular}

While the Micrococcaceae counts remained at about $6.00 \mathrm{log} \mathrm{cfu} / \mathrm{g}$ until the end of seasoning, lactic acid bacteria showed a progressive increase reaching $8.70 \mathrm{log} \mathrm{cfu} / \mathrm{g}$ between the 3rd and 8th days and did not change until at the end of ripening. Throughout this period, the lactic acid bacteria produced a strong fermentation activity highlighted by the corresponding lowering of the $\mathrm{pH}$ values. Enterobacteriaceae from the initial viable count underwent a progressive decrease until reaching a value of $0.70 \log \mathrm{cfu} / \mathrm{g}$ below the microbiological limit of contamination $(<10 \mathrm{cfu} / \mathrm{g})$ determined for the meat from the 8 th day onwards [34]. A similar trend was observed for S. aureus, which already recorded values of $1.70 \log \mathrm{cfu} / \mathrm{g}$ below the microbiological limit of contamination $(<100 \mathrm{cfu} / \mathrm{g})$ from the 3rd day [34].

\subsection{Physico-Chemical Parameters of Sausages}

The initial $\mathrm{pH}$ (average of 5.80) decreased in all sausages at the end of ripening. During storage, the $\mathrm{pH}$ value was 5.4, while at the end of seasoning, the $\mathrm{pH}$ decreased further to 5.10. At the same time, the aw value decreased from 0.96 at the beginning of the process to 0.84 after storage (28th day). The decrease was slow over time with values of 0.93 and 0.89 during the ripening ( 8 th and 17th days, respectively). The decrease in $\mathrm{pH}$ and aw values during the seasoning is ordinary for this food process. Regarding the weight, from an initial value of about $370 \mathrm{~g}$, a decrease in all samples up to an average value of $39.23 \%$ at the end of seasoning was observed, which is a fluctuation that is consistent with the usual production trend (Table S1).

\subsection{Growth Control of L. monocytogenes by Plant Extracts in Artificially Contaminated Cooked Ham}

Figures 2 and 3 show the plant extracts effectiveness against $L$. monocytogenes artificially inoculated in cooked ham slices. The test, performed during the shelf-life at $4{ }^{\circ} \mathrm{C}$ of the product using two different levels of contamination, demonstrated that, unlike sausages, the cooked ham, due to its intrinsic characteristics ( $\mathrm{pH}$, aw, etc.) allows for the growth of the pathogen. The samples CLM3 untreated with plant extracts and inoculated with the higher concentration (on average $3.74 \mathrm{log} \mathrm{cfu} / \mathrm{g}$ of L. monocytogenes) showed $5.48 \mathrm{log} \mathrm{cfu} / \mathrm{g}$ viable counts after 8 days, $7.33 \log \mathrm{cfu} / \mathrm{g}$ after 15 days and a greater $8.00 \log \mathrm{cfu} / \mathrm{g}$ at the end of shelf-life (Figure 2).

In PELM3 samples treated with plant extracts, the activity of the compound immediately after treatment is highlighted from a decrease of about $1.00 \log \mathrm{cfu} / \mathrm{g}$ of $L$. monocytogenes (the counts recorded were between 2.04 and $2.70 \log \mathrm{cfu} / \mathrm{g}$ ). After 8 days of storage, L. monocytogenes viable counts increased up to $4.11 \mathrm{log} \mathrm{cfu} / \mathrm{g}$, and they increased up to $6.05 \log \mathrm{cfu} / \mathrm{g} 15$ days later, reaching $7.86 \log \mathrm{cfu} / \mathrm{g}$ at the end of the product shelf-life (Figure 2). The difference between CLM3 and PELM3 was significant during the test ( $p$-value $<0.01)$, with an average difference of $1.00 \mathrm{log}$. On the 5th and the 12 th day after contamination, the difference between treated and untreated ham slices was of $2.00 \mathrm{log}$ ( $p$-value $<0.001)$. 


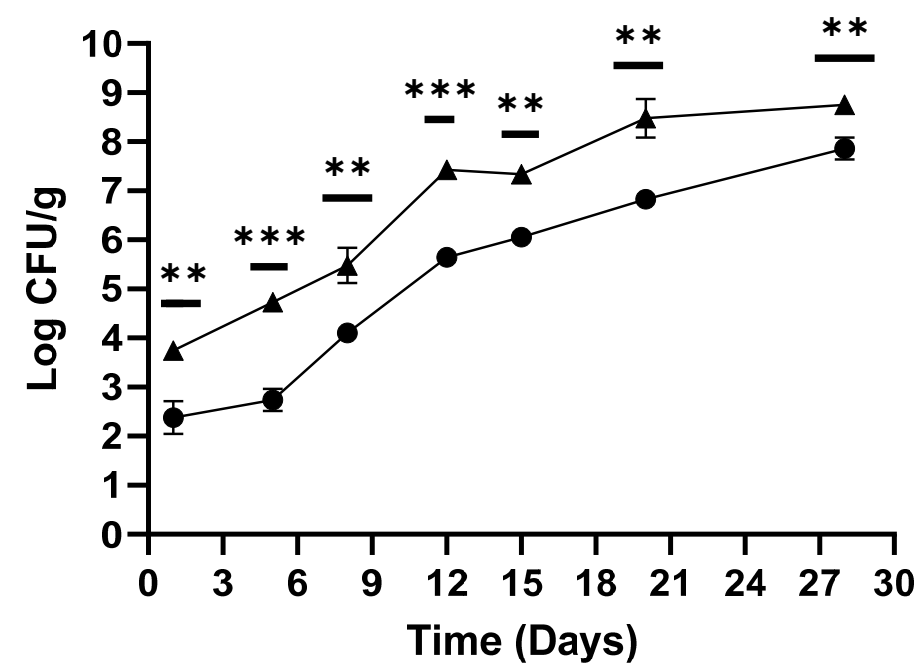

$\rightarrow$ PELM3

$\leftarrow$ CLM3

Figure 2. Trend of L. monocytogenes during shelf-life of ham cooked with (PELM3) and without (CLM3) plant extract. $p$-values of ${ }^{*}<0.05,{ }^{* *} p<0.01,{ }^{* * *} p<0.001$ and ${ }^{* * * *} p<0.0001$ were considered significant by $t$-test and ANOVA. ns means not significant.

In the cooked ham inoculated with the lower microbial concentration (on average 2.05 $\log \mathrm{cfu} / \mathrm{g}$ of L. monocytogenes) a similar trend was observed. In samples CLM2 untreated an increase in Listeria viable counts of almost $1.00 \mathrm{log} \mathrm{cfu} / \mathrm{g}$ was recorded from the 5th day; this value increased to $4.00 \log \mathrm{cfu} / \mathrm{g}$ at 12 th day and remains unchanged until to the end of shelf-life (Figure 3).

In the slices treated with the plant extracts (PELM2), in the first 5 days after treatment, we observed a reduction of about $1.00 \mathrm{log}$, with viable counts of L. monocytogenes reaching on average $0.87 \log \mathrm{cfu} / \mathrm{g}$. From the 5 th to the 12 th day of experimentation, the greatest differences in the growth of L. monocytogenes were exhibited in the two samples (PELM2 and CLM2), with a difference of $2.00 \log (p$-values $<0.001)$. After 15 days, in the treated sample (PELM2,) the pathogen growth increased up to about $3.00 \mathrm{log} \mathrm{cfu} / \mathrm{g}$ and then remained constant until the end of the shelf-life (Figure 3). The difference between the two samples decreased from the 15th day ( $p$-values $<0.01$ ) until the end of the test ( $p$-values $<0.05$ ) due to the unchanging L. monocytogenes growth in both the treated and untreated ham slices.

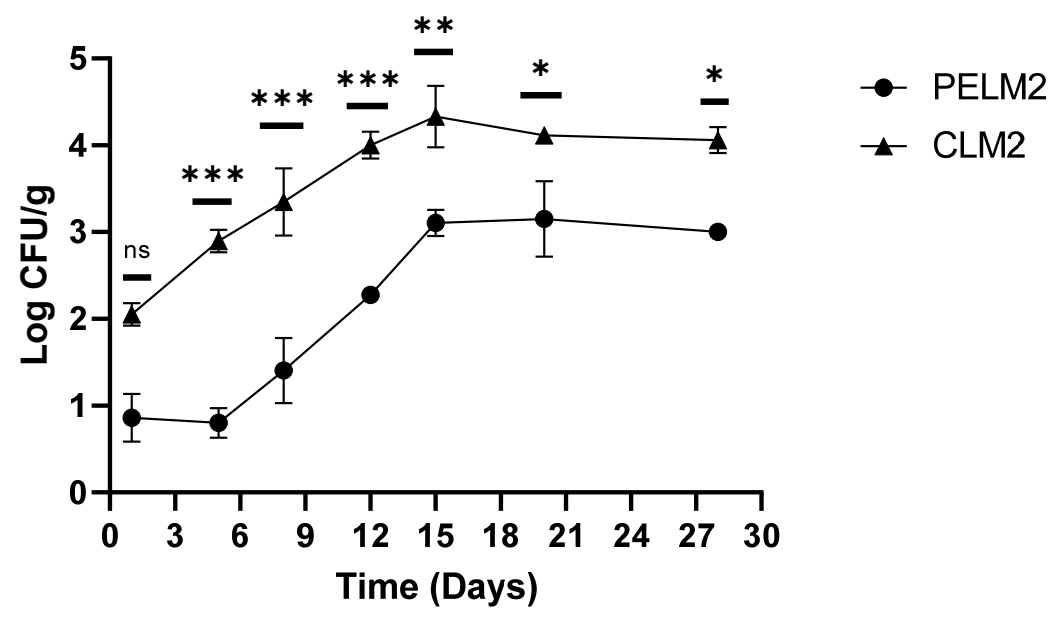

Figure 3. Trend of L. monocytogenes during shelf-life of ham cooked with (PELM2) and without (CLM2) plant extract. $p$-values of ${ }^{*}<0.05,{ }^{* *} p<0.01,{ }^{* * *} p<0.001$ and ${ }^{* * * *} p<0.0001$ were considered significant by $t$-test and ANOVA. ns means not significant. 
In summary, the results of the study carried out using two different levels of contamination showed that the plant extracts added in cooked ham slices produced a slow down of the potential growth rate of L. monocytogenes compared to the untreated control. Cooked ham is commonly considered a safe product, but recontamination by psychrotrophic pathogens such as L. monocytogenes can occur during post-processing. The use of plant extracts can determine the elimination of the pathogens; however, the effectiveness of this inhibition is strongly correlated to the quantity of the pathogen and of the plant extracts used.

\subsection{Assessment of Growth Speed Using MicroFit Software@}

The growth rate of L. monocytogenes on cooked ham was estimated through a nonlinear regression using the MicroFit@ software. The behavior in the two lines treated and untreated with plant extracts were different, and this outcome was also to be attributed to the initial bacterial contamination level. The statistical data show that the use of plant extracts, in samples inoculated with $10^{3} \mathrm{cfu} / \mathrm{g}$ (average $3.74 \log \mathrm{cfu} / \mathrm{g}$ ), caused a reduction of about $1.50 \mathrm{log}$ in the $24 \mathrm{~h}$ following the treatment, but did not affect the duration of the lag phase or the growth rate in the subsequent days. In samples inoculated with $10^{2} \mathrm{cfu} / \mathrm{g}$ (average $2.05 \log \mathrm{cfu} / \mathrm{g}$ ), the treatment, in addition to an initial reduction of about $1.00 \log$, produced an extension of the lag phase of the surviving cells (from 1.40 to 7.70 days) and a reduction in the growth rate. It can therefore be assumed that the activity of the plant extracts is also related to the initial level of L. monocytogenes contamination. Considering that the degree of recontamination in the shearing phase and/or slicing of the cooked ham usually does not exceed $10 \mathrm{cfu} / \mathrm{g}$, our results support the use of the plant extracts as an adjuvant in containing the pathogen growth.

\subsection{Trend of Physico-Chemical Parameters in Cooked Ham}

The impact of the plant extracts on the physico-chemical features during the cooked ham shelf-life in the samples treated and untreated was monitored. The $\mathrm{pH}$ value initially recorded in PEC and in C samples was 6.02 and 6.11, respectively, and did not change substantially during storage ( 28 days at $4{ }^{\circ} \mathrm{C}$ ). Even the aw values recorded for both types of samples were similar showing an average value around 0.97 at all deadlines. These results are in conformity with what is expected for this type of production (Table S2).

\section{Discussion}

In the present investigation, the antibacterial capability of plant extracts containing natural compounds derived from garlic and onion was tested against the psychrotrophic foodborne pathogen L. monocytogenes, which was artificially inoculated in sausages and in cooked ham slices. The antibacterial activities of these natural compounds are attributed to the high content of organo-sulfur compounds, including diallyl sulfide (DAS), diallyl disulfide (DADS), diallyl trisulfide (DATS) and their precursors that destroy the structure and the metabolic process of bacterial cells [40-42]. Most studies carried out on the antimicrobial activity of natural products against foodborne pathogens have only been performed in cultural substrates, but the structure and composition of foods, as well as conservation conditions, can influence the effectiveness of the antagonistic compounds $[15,43,44]$. Firouzi et al. [45] reported that higher levels of oregano and nutmeg extracts were needed to contain the growth of L. monocytogenes in roast chicken than in culture medium trials, and according to Singh et al. [46], the antibacterial activity of both clove and thyme extracts added to a culture broth was significantly lower than that obtained in a food matrix, such as hot dogs. Consequently, the real effectiveness of natural antibacterial compounds should be directly evaluated in food substrates. In the tests carried out during sausages manufacturing, we observed a reduction of Listeria viable counts, but the decrease does not differ between treated and untreated samples. Furthermore, during sausage seasoning, a reduction in the $\mathrm{pH}$ and aw values was detected, as also observed by Morales-Partera for L. innocua [47]. These results were in accordance with Sun et al. [48], who reported that 
heat-dried Chinese-style sausages containing garlic had no significant differences between the samples. The rate of inactivation that naturally occurs during seasoning and is related to several factors (presence of microbial starters, acidity of the substrate, decreasing activity of water, etc.), and could explain the lack of an evident antibacterial action due to the addition of the plant extracts. Indeed, L. monocytogenes exhibits compensatory mechanisms to adapt to stressful conditions such as low $\mathrm{pH}$, low aw or low temperature, which may explain the increased survival along the seasoning process [49]. The tolerance of this pathogen to the dry-curing process is probably related to its tolerance to salts and low temperatures in the presence of organic material and underlines the importance of controlling L. monocytogenes during the processing of cured products [50]. Meat and meat products are a complex environment of organic materials, and some constituents may even provide microbial cells protection from antimicrobial substances. Cutter et al. [51] suggested that fat in foods could protect them from antimicrobial agents by forming a protective layer around bacteria. On the other hand, the test performed on sliced vacuum-packaged cooked ham showed, immediately after the addition of the plant extracts, the decrease of the $L$. monocytogenes contamination of about $1.00 \mathrm{log} \mathrm{cfu} / \mathrm{g}$. L. monocytogenes was sensitive to spice extracts, which was probably due, at least in part, to the fact that those cooked ham slices were leaner than the sausages. These results were in agreement with Somrani et al. 2020 [40], who reported the antibacterial activity of garlic and onion essential oils towards L. monocytogenes. Other authors reported the antimicrobial activities of garlic and onion against pathogenic bacteria including Salmonella Typhimurium, Escherichia coli O157:H7, Listeria monocytogenes, Staphylococcus aureus and Campylobacter jejuni [52,53]. The plant extracts do not appear to interfere with the physico-chemical features of the cooked ham, and the $\mathrm{pH}$ and aw values recorded did not change during the shelf-life of this product.

Considering that, in cooked ham, the presence of L. monocytogenes does not exceed $10 \mathrm{cfu} / \mathrm{g}$, the use of plant extracts can determine the complete elimination of the pathogen. In fact, cooked ham is commonly considered a safe product, but recontamination can occur during post-processing. Some pathogens such as L. monocytogenes can still grow during refrigerator storage, while the development of 'classic' foodborne pathogens is inhibited by low temperatures used to preserve this product. For this reason, the cooked ham was contaminated with L. monocytogenes using two concentrations, both overestimated $\left(10^{2}\right.$ and $10^{3} \mathrm{cfu} / \mathrm{g}$ ) considering the usual presence of the pathogen in this type of meat product. In sausage samples, greater quantities of L. monocytogenes than the cooked ham slices were added, as the curing process takes place at room temperature, which is an environment suitable for the growth of both psychrotrophic and mesophilic bacteria.

\section{Conclusions}

To improve safety and quality, natural compounds endowed with antimicrobial activity could be employed during the production process. Considering the results that emerged from the present investigation, we can assume that, during the ripening of the sausages, the plant extracts tested do not produce further advantages on the control of foodborne pathogens due to $\mathrm{pH}$ and aw decreases. The use of this natural compound seems to be a useful technological adjuvant for the control of L. monocytogenes in other types of meat products, such as sliced vacuum-packaged cooked ham or other cooked meat products stored at refrigeration temperature. However, further studies are necessary to better define the potential of these types of natural products in the field of bio-preservation, exploiting the possibility of synergies between them and carefully evaluating the role of food composition in determining their effectiveness.

Supplementary Materials: The following files are available online https:/ /www.mdpi.com/article/ 10.3390/app112210820/s1, Table S1: Physico-chemical parameters of sausages "cacciatore" standard dough. The $\mathrm{pH}$ and aw values are expressed as mean \pm standard deviation (SD). Table S2: Physicochemical parameters in cooked ham. C-square slices (control) and PEC-square slices with plant extract added $(10 \mu \mathrm{L} / \mathrm{g})$. The $\mathrm{pH}$ and aw values are expressed as mean \pm standard deviation (SD) of three determinations. ns means no statistical differences between PEC and C by $t$-test and ANOVA. 
Author Contributions: Conceptualization, S.d.N., R.I. and P.M.; methodology, R.I., C.S., and S.C.; validation, R.I. and C.S.; investigation, R.I. and S.C.; resources, C.S., M.B. and P.M.; data curation, P.M., R.I. and S.d.N.; writing-original draft preparation S.d.N., R.I. and S.C.; writing-review and editing, P.M., R.I. and C.S.; visualization, S.C. and R.I.; supervision, P.M. and C.S.; project administration, S.d.N., M.B. and P.M.; funding acquisition, M.B. and P.M. All authors have read and agreed to the published version of the manuscript.

Funding: This research received no external funding.

Institutional Review Board Statement: Not applicable.

Informed Consent Statement: Not applicable.

Acknowledgments: Special acknowledgment to Silvana Barbuti (experimental station for the food preserving industry-S.S.I.C.A., Parma, Italy) for his very useful suggestions and comments.

Conflicts of Interest: The authors declare no conflict of interest.

\section{References}

1. Negi, P.S. Plant extracts for the control of bacterial growth: Efficacy, stability and safety issues for food application. Int. J. Food Microbiol. 2012, 156, 7-17. [CrossRef] [PubMed]

2. Dumay, E.; Chevalier-Lucia, D.; López-Pedemonte, T. High pressure and food conservation. In Comparative High-Pressure Biology; Sebert, P., Ed.; CRC Press: Boca Raton, FL, USA, 2010; pp. 85-118.

3. Rezaeigolestani, M.; Misaghi, A.; Khanjari, A.; Basti, A.A.; Abdulkhani, A.; Fayazfar, S. Antimicrobial evaluation of novel poly-lactic acid based nanocomposites incorporated with bioactive compounds in-vitro and in refrigerated vacuum-packed cooked sausages. Int. J. Food Microbiol. 2017, 260, 1-10. [CrossRef] [PubMed]

4. Ahmed, J.; Arfat, Y.A.; Bher, A.; Mulla, M.; Jacob, H.; Auras, R. Active chicken meat packaging based on polylactide films and bimetallic Ag-Cu nanoparticles and essential oil. J. Food Sci. 2018, 83, 1299-1310. [CrossRef] [PubMed]

5. Domínguez, R.; Barba, F.J.; Gómez, B.; Putnik, P.; Bursać Kovačević, D.; Pateiro, M.; Santos, E.M.; Lorenzo, J.M. Active packaging films with natural antioxidants to be used in meat industry: A review. Food Res. Int. 2018, 113, 93-101. [CrossRef] [PubMed]

6. Iseppi, R.; Pilati, F.; Marini, M.; Toselli, M.; de Niederhäusern, S.; Guerrieri, E.; Messi, P.; Sabia, C.; Manicardi, G.; Anacarso, I.; et al. Anti-listerial activity of a polymeric film coated with hybrid coatings doped with Enterocin 416K1 for use as bioactive food packaging. Int. J. Food Microbiol. 2008, 123, 281-287. [CrossRef]

7. Iseppi, R.; de Niederhäusern, S.; Anacarso, I.; Messi, P.; Sabia, C.; Pilati, F.; Toselli, M.; Degli Esposti, M.; Bondi, M. Anti-listerial activity of coatings entrapping living bacteria. Soft Matter 2011, 7, 8542-8548. [CrossRef]

8. Aziz, M.; Karboune, S. Natural antimicrobial/antioxidant agents in meat and poultry products as well as fruits and vegetables: A review. Crit. Rev. Food Sci. Nutr. 2018, 58, 486-511. [CrossRef]

9. Degli Esposti, M.; Toselli, M.; Sabia, C.; Messi, P.; de Niederhäusern, S.; Bondi, M.; Iseppi, R. Effectiveness of polymeric coated films containing bacteriocin-producer living bacteria for Listeria monocytogenes control under simulated cold chain break. Food Microbiol. 2018, 76, 173-179. [CrossRef]

10. Rojas-Graü, M.A.; Garner, E.; Martin-Belloso, O. The fresh-cut fruit and vegetables industry current situation and market trends. In Advances in Freshcut Fruits and Vegetables Processing; Martin-Belloso, O., Soliva-Fortuny, R., Eds.; CRC Press: Boca Raton, FL, USA, 2011; pp. 1-11. [CrossRef]

11. Ananou, S.; Maqueda, M.; Martinez-Bueno, M.; Valdivia, E. Biopreservation, an ecological approach to improve the safety and shelf-life of foods. Commun. Curr. Res. Educ. Top. Trends Appl. Microbiol. 2007, 1, 475-486. [CrossRef]

12. Horbanczuk, O.K.; Kurek, M.A.; Atanasov, A.G.; Brnci'c, M.; RimacBrncic, S. The effect of natural antioxidants on quality and shelf life of beef and beef products. Food Technol. Biotechnol. 2019, 57, 439-447. [CrossRef]

13. Odeh, D.; Kraljić, K.; Benussi Skukan, A.; Škevin, D. Oxidative stability, microbial safety, and sensory properties of flaxseed (Linum usitatissimum L.) oil infused with spices and herbs. Antioxidants 2021, 10, 785. [CrossRef]

14. Halagarda, M.; Wójciak, K.M. Health and safety aspects of traditional European meat products. A review. Meat Sci. 2021, 184, 108623. [CrossRef]

15. Bondi, M.; Lauková, A.; de Niederhausern, S.; Messi, P.; Papadopoulou, C. Natural preservatives to improve food quality and safety. J. Food Qual. 2017, 2017, 1090932. [CrossRef]

16. Chatzidaki, M.D.; Balkiza, F.; Gad, E.; Alexandraki, V.; Avramiotis, S.; Georgalaki, M.; Papadimitriou, V.; Tsakalidou, E.; Papadimitriou, K.; Xenakis, A. Reverse micelles as nano-carriers of nisin against foodborne pathogens. Part II: The case of essential oils. Food Chem. 2019, 278, 415-423. [CrossRef]

17. Iseppi, R.; Sabia, C.; de Niederhäusern, S.; Pellati, F.; Benvenuti, S.; Tardugno, R.; Bondi, M.; Messi, P. Antibacterial activity of Rosmarinus officinalis L. and Thymus vulgaris L. essential oils and their combination against food-borne pathogens and spoilage bacteria in ready-to-eat vegetables. Nat. Prod. Res. 2019, 33, 3568-3572. [CrossRef]

18. Kalogianni, A.I.; Lazou, T.; Bossis, I.; Gelasakis, A.I. Natural phenolic compounds for the control of oxidation, bacterial spoilage, and foodborne pathogens in meat. Foods 2020, 9, 794. [CrossRef] 
19. Gutierrez, J.; Rodriguez, G.; Barry-Ryan, C.; Bourke, P. Efficacy of plant essential oils against foodborne pathogens and spoilage bacteria associated with ready-to-eat vegetables: Antimicrobial and sensory screening. J. Food Prot. 2008, 71, 1846-1854. [CrossRef]

20. Selim, S. Antimicrobial activity of essential oils against vancomycin-resistant enterococci (vre) and Escherichia coli O157:h7 in feta soft cheese and minced beef meat. Braz. J. Microbiol. 2011, 42, 187-196. [CrossRef] [PubMed]

21. De Oliveira, M.M.; Brugnera, D.F.; Piccoli, R.H. Essential oils of thyme and rosemary in the control of Listeria monocytogenes in raw beef. Braz. J. Microbiol. 2014, 44, 1181-1188. [CrossRef] [PubMed]

22. González-Molina, E.; Domínguez-Perles, R.; Moreno, D.A.; García-Viguera, C. Natural bioactive compounds of Citrus limon for food and health. J. Pharm. Biomed. Anal. 2010, 51, 327-345. [CrossRef] [PubMed]

23. Anacarso, I.; de Niederhäusern, S.; Iseppi, R.; Sabia, C.; Bondi, M.; Messi, P. Anti-listerial activity of chitosan and Enterocin 416K1 in artificially contaminated RTE products. Food Control. 2011, 22, 2076-2080. [CrossRef]

24. Wan Yahaya, W.A.; Abu Yazid, N.; Mohd Azman, N.A.; Almajano, M.P. Antioxidant activities and total phenolic content of malaysian herbs as components of active packaging film in beef patties. Antioxidants 2019, 8, 204. [CrossRef]

25. De Niederhäusern, S.; Camellini, S.; Sabia, C.; Iseppi, R.; Bondi, M.; Messi, P. Antilisterial activity of bacteriocins produced by lactic bacteria isolated from dairy products. Foods 2020, 9, 1757. [CrossRef]

26. Mehdizadeh, T.; Tajik, H.; Langroodi, A.M.; Molaei, R.; Mahmoudian, A. Chitosan-starch film containing pomegranate peel extract and Thymus kotschyanus essential oil can prolong the shelf life of beef. Meat Sci. 2020, 163, 108073. [CrossRef] [PubMed]

27. Samelis, J.; Kakouri, A.; Georgiadou, K.G.; Metaxopoulos, J. Evaluation of the extent and type of bacterial contamination at different stages of processing of cooked ham. J. Appl. Microbiol. 1998, 84, 649-660. [CrossRef]

28. Kivanç, M.; Akgül, A.; Doğan, A. Inhibitory and stimulatory effects of cumin, oregano and their essential oils on growth and acid production of Lactobacillus plantarum and Leuconostoc mesenteroides. Int. J. Food Microbiol. 1991, 13, 81-85. [CrossRef]

29. Quesada, J.; Sendra, E.; Navarro, C.; Sayas-Barberá, E. Antimicrobial active packaging including chitosan films with Thymus vulgaris L. essential oil for ready-to-eat meat. Foods 2016, 5, 57. [CrossRef]

30. Tajkarimi, M.M.; Ibrahim, S.A.; Cliverb, D.O. Antimicrobial herb and spice compounds in food. Food Control 2010, 21, 1199-1218. [CrossRef]

31. CLSI. Performance Standards for Antimicrobial Susceptibility Testing, 29th ed.; Clinical and Laboratory Standards Institute: Wayne, PA, USA, 2019; Volume 39.

32. ISO 4833-1. Microbiology of the Food Chain-Horizontal Method for the Enumeration of Microorganisms—Part 1: Colony Count at 30 Degrees C by the Pour Plate Technique. 2013. Available online: https://www.iso.org/standard/53728.html (accessed on 22 September 2021).

33. ISO 15214. Microbiology of Food and Animal Feeding Stuffs-Horizontal Method for the Enumeration of Mesophilic Lactic Acid Bacteria-Colony-Count Technique at 30 Degrees C. 1998. Available online: https://www.iso.org/standard/26853.html (accessed on 22 September 2021).

34. UNI EN ISO 6888-1. Microbiology of Food and Animal Feed-Horizontal Method for Counting Coagulase-Positive Staphylococci (Staphylococcus aureus and Other Species)—Technique Using Baird-Parke Agar Medium. 2004. Available online: http:/ /store.uni. com/catalogo/uni-en-iso-6888-1-2004 (accessed on 22 September 2021).

35. ISO 21528-2. Microbiology of Food and Animal Feeding Stuffs-Horizontal Methods for the Detection and Enumeration of Enterobacteriaceae-Part 2: Colony-Count Method. 2004. Available online: http://store.uni.com/catalogo/iso-21528-2-2004 (accessed on 22 September 2021).

36. UNI EN ISO 11290-1. Microbiology of the Food Chain-Horizontal Method for the Detection and Enumeration of Listeria monocytogenes and of Listeria spp.-Part 1: Detection Method. 2005. Available online: http://store.uni.com/catalogo/uni-en-iso11290-1-2005 (accessed on 22 September 2021).

37. UNI EN ISO 6579. Microbiology of Food and Animal Feeding Stuffs-Horizontal Method for the Detection of Salmonella spp. 2008. Available online: http:/ / store.uni.com/catalogo/uni-en-iso-6579-2008 (accessed on 22 September 2021).

38. UNI EN ISO 11290-2. Food Chain Microbiology-Horizontal Method for Research and Counting of Listeria monocytogenes and Listeria spp.-Part 2: Method for Counting Microbiology of the Food Chain-Horizontal Method for the Detection and Enumeration of Listeria monocytogenes and of Listeria spp.-Part 2: Enumeration Method. 2017. Available online: https: / / www.iso.org/standard/60314.html (accessed on 22 September 2021).

39. European Union Reference Laboratory for Listeria monocytogenes. Technical guidance document for conducting shelf-life studies on Listeria monocytogenes in ready-to-eat foods. In EURL Lm Technical Guidance Document; EURL Lm, European Union Reference Laboratory for Listeria Monocytogenes: Maisons-Alfort, France, 2014; pp. 1-47.

40. Somrani, M.; Inglés, M.C.; Debbabi, H.; Abidi, F.; Palop, A. Garlic, onion, and cinnamon essential oil anti-biofilms' effect against Listeria monocytogenes. Foods 2020, 9, 567. [CrossRef] [PubMed]

41. Andualem, B. Combined antibacterial activity of stingless bee (Apis mellipodae) honey and garlic (Allium sativum) extracts against standard and clinical pathogenic bacteria. Asian Pac. J. Trop. Biomed. 2013, 3, 725-731. [CrossRef]

42. Shang, A.; Cao, S.Y.; Xu, X.Y.; Gan, R.Y.; Tang, G.Y.; Corke, H.; Mavumengwana, V.; Li, H.B. Bioactive compounds and biological functions of garlic (Allium sativum L.). Foods 2019, 8, 246. [CrossRef] [PubMed]

43. Jamel, D.; Javier, Y.; Luis, M.; Mouloud, D. Antimicrobial activity of Pistacia lentiscus and Satureja montana essential oils against Listeria monocytogenes CECT 935 using laboratory media: Efficacy and synergistic potential in minced beef. Food Control 2011, 22, 1046-1053. [CrossRef] 
44. Iseppi, R.; Camellini, S.; Sabia, C.; Messi, P. Combined antimicrobial use of essential oils and bacteriocin bacLP17 as seafood biopreservative to control Listeria monocytogenes both in planktonic and in sessile forms. Res. Microbiol. 2020, 171, $351-356$. [CrossRef] [PubMed]

45. Firouzi, R.; Shekarforoush, S.S.; Nazer, A.H.; Borumand, Z.; Jooyandeh, A.R. Effects of essential oils of oregano and nutmeg on growth and survival of Yersinia enterocolitica and Listeria monocytogenes in barbecued chicken. J. Food Prot. 2007, 70, 2626-2630. [CrossRef]

46. Singh, A.; Singh, R.; Bhunia, A.; Singh, N. Efficacy of plant essential oils as antimicrobial agents against Listeria monocytogenes in hotdogs. LWT-Food Sci. Technol. 2003, 36, 787-794. [CrossRef]

47. Morales-Partera, Á.M.; Cardoso-Toset, F.; Jurado-Martos, F.; Astorga, R.J.; Huerta, B.; Luque, I.; Tarradas, C.; Gómez-Laguna, J. Survival of selected foodborne pathogens on dry cured pork loins. Int. J. Food Microbiol. 2017, 258, 68-72. [CrossRef]

48. Sun, Y.M.; Ockerman, H.W.; Marriott, N.G. Garlic in Chinese sausage. J. Muscle Foods 2000, 11, 35-43. [CrossRef]

49. García-Díez, J.; Alheiro, J.; Pinto, A.L.; Soares, L.; Falco, V.; Fraqueza, M.J.; Patarata, L. Behaviour of food-borne pathogens on dry cured sausage manufactured with herbs and spices essential oils and their sensorial acceptability. Food Control 2016, 59, 262-270. [CrossRef]

50. Magalhães, R.; Ferreira, V.; Brandão, T.R.S.; Palencia, R.C.; Almeida, G.; Teixeira, P. Persistent and non-persistent strains of Listeria monocytogenes: A focus on growth kinetics under different temperature, salt, and $\mathrm{pH}$ conditions and their sensitivity to sanitizers. Food Microbiol. 2016, 57, 103-108. [CrossRef]

51. Cutter, C.N.; Hruska, L. Antimicrobial effect of herb extracts against Escherichia coli O157:H7, Listeria monocytogenes and Salmonella Typhimurium associated with beef. J. Food Prot. 2000, 63, 601-607. [CrossRef]

52. Yin, M.C.; Cheng, W.S. Antioxidant and antimicrobial effects of four garlic-derived organosulfur compounds in ground beef. Meat Sci. 2003, 63, 23-28. [CrossRef]

53. Benkeblia, N. Antimicrobial activity of essential oil extracts of various onions (Allium cepa) and garlic (Allium sativum). LWT-Food Sci. Technol. 2004, 37, 263-268. [CrossRef] 